\title{
Legal Issues in Medical Management of Violent and Threatening Patients
}

\author{
Bernard Dickens
}

\author{
Version Publisher's Version \\ Citation Bernard Dickens, "Legal Issues in Medical Management of Violent and \\ (published version) Threatening Patients" (1986) 31 Canadian Journal of Psychiatry 772.
}

Copyright / License Copyright (C) 1986. This article was first published in the Canadian Journal of Psychiatry 31 (1993), 772. Reprinted with permission.

\section{How to cite TSpace items}

Always cite the published version, so the author(s) will receive recognition through services that track citation counts, e.g. Scopus. If you need to cite the page number of the author manuscript from TSpace because you cannot access the published version, then cite the TSpace version in addition to the published version using the permanent URI (handle) found on the record page.

This article was made openly accessible by $U$ of 'T Faculty. Please tell us how this access benefits you. Your story matters. 


\title{
Legal Issues in Medical Management of Violent and Threatening Patients*
}

\author{
BERNARD M. DICKENS, Ph.D., LL.D. ${ }^{1}$
}

The responsibility of professionals in the medical management of violent and threatening patients is discussed using the Tarasoff case (American) and the Lawson case (Canadian) as landmark cases influencing subsequent jurisprudence.

It is becoming increasingly important to be aware of the court's interpretations in such areas as confidentiality, predictions regarding dangerousness, the duty to warn, and the legal duty to strangers to the therapist / patient relationship. A number of other issues relating to the risks involved in management of patients potentially dangerous as a result of the use of drugs are also discussed.

I $t$ is a great honour for me to have been invited to deliver the Kenneth G. Gray Memorial Lecture. To be in line of succession to such past lecturers as Professors Nigel Walker, Joseph Goldstein, Donald West and John Gunn is both flattering and humbling. Special pleasure comes from being the first Canadian national to so honour the memory of a pioneer of Canadian forensic psychiatry, coming from his own university, and holding appointments in the two departments that gained most benefit from the dedication of his life's work, the Faculty of Law and the Faculty of Medicine.

As both a psychiatrist and a lawyer, Kenneth G. Gray spent his professional life at the intersection of psychiatry, law and legislation. Further, I believe that he entered his two professions in a wise sequence, graduating first in medicine, in 1928, specializing in psychiatry from 1931, and graduating in law and being called to the Bar in 1935. His initial concern with psychiatry, the therapeutic treatment of mentally disordered people, may have shown how prevention, management and cure of mental disorder, and also punishment and correction of those disordered but not legally insane persons who victimize their neighbours,

\footnotetext{
*This was delivered as the Kenneth G. Gray Memorial Lecture, at the Canadian Psychiatric Association Annual Meeting in Quebec City, October 3, 1985 .

IFaculty of Law and Faculty of Medicine, University of Toronto. Address reprint requests to: Professor Bernard M. Dickens, Faculty of Law, University of Toronto, 78 Queen's Park, Toronto, Ontario M5S $2 \mathrm{CS}$
}

Can. J. Psychiatry Vol. 31, November 1986 constantly engage the machinery of law and the processes of the courts. As Legal Counsel to the Ontario Department of. Health and one of the draftsmen of the provincial Mental Hospitals Act of 1935, Dr. Gray also saw the inner workings of the legislative process. His professional skills, career experience and personal qualities are missed today not only by the colleagues and friends who knew him, but also by a later generation of both psychiatrists and lawyers seeking to give effect to Canada's new Charter of Rights and Freedoms. The Charter guarantees to all persons the legal rights to "life, liberty and security of the person", the right "not to be deprived thereof except in accordance with the principles of fundamental justice", (Charter, s. 7) and "the right to the equal protection and equal benefit of the law without discrimination ... based on ... mental or physical disability" (s. 15)(l).

The particular topic of the memorial lecture is one that Dr. Gray faced in the legal environment of his time. Legal issues in the medical management of violent and threatening patients are, however, perhaps more familiar to the psychiatric profession now than they once were, because of the visibility and impact of judicial decisions, particularly on the so-called "duty to warn." In addressing the topic, I want to go beyond legally indicated psychiatric responses to violence, and consider the threat presented by inadvertent dangerousness. This may arise when non-violent patients, including outpatients, become reckless in predictable ways because of, for instance, prescribed medications, or because of inability to control motor vehicles or other means of causing injury.

The watershed legal decisions on psychiatric responses to predictable danger came in the 1974 and 1976 cases of Tarasoff vs. Regents of the University of California,(1) and in the less well known but no less significant judgment of the Supreme Court of Canada in 1977 in Wellesley Hospital vs. Lawson (2).

\section{The Tarasoff and Lawson Cases}

There can be very few if any Canadian psychiatrists practising today who are unaware of the Tarasoff case. It arose, of course, when a student who had been receiving psychiatric treatment as a voluntary outpatient at the University's hospital told a psychologist there of his intention to kill a young woman to whom he had formed 
an emotional attachment. The psychologist, acting under a supervising psychiatrist, recognized that the student represented an actual danger to the woman's safety. The campus police were informed and they briefly detained the student, but released him because he appeared rational. The psychiatrist directed that no further action be taken, although the student ceased to attend for treatment. In order to preserve confidentiality, no one beyond the campus police was told of the danger found to exist to the woman. The student subsequently arranged to share an apartment with the woman's brother, and when he and the woman met again, he killed her in a brutal attack. He was criminally. convicted for second degree murder, but the conviction was reversed on appeal on account of his insanity (3).

The civil action for compensation brought on behalf of the victim's estate was based on the claim that the mental health professionals involved with the student violated their legal duty towards her because they should have warned her or someone concerned for her safety of the danger found to exist. Three defences were proposed:

a) that the duty of confidentiality precluded disclosure of the patient's dangerous propensity;

b) that psychiatry possesses no predictive powers regarding dangerousness on which a duty to warn can reasonably be based, and

c) that no legal duty was owed to a stranger to the therapist-patient relationship.

All three defences failed, and we have to consider the principles underlying the judicial approach taken, and their implications. The Supreme Court of Canada has shown a willingness to apply Californian and general United States'jurisprudence in the area, for instance, of medical consent (4); its decision in the Lawson case, the year after the Tarasoff judgment, shows that the Tarasoff principles are highly relevant to Canada.

The defence of confidentiality failed because it was held that the victim's interest in protection against anticipated danger was more important than the patient's interest in privacy. The Supreme Court of California recognized that competing interests had to be weighed against each other, observing that:

We recognize the public interest in supporting effective treatment of mental illness and in protecting the rights of patients to privacy, and the consequent public importance of safeguarding the confidential character of psychotherapeutic communication. Against this interest, however, we must weigh the public interest in safety from violent assault (5).

The court favoured safety over confidentiality in its conclusion that:

The public policy favoring protection of the confidential character of patient-psychotherapist communications must yield to the extent to which disclosure is essential to avert danger to others. The protective privilege ends where the public peril begins (6).

This assessment opens the way not only to the legal duty to warn particular predicted victims, but also to the duty, where individual victims cannot be identified and warned, to use legal powers of involuntary detention of persons found to be dangerous to others in general. It converts the statutory power to protect the public into a duty owed to any and every member of the undifferentiated public who may be hurt from a predicted source of danger, and includes a duty to a patient found to be dangerous to himself or herself.

The second defence used in the Tarasoff case, that of psychiatric inability to predict dangerousness, has come to be accepted in a general sense in the years since the 1976 judgment. The American Psychiatric Association presented a brief to the Supreme Court of California alleging that psychiatrists can profess no special accuracy in prediction of danger from an individual patient (7). A sizable literature, generated in large part by the Tarasoff judgment, has established the limits of psychiatric prediction (8), but it must be remembered that the Tarasoff court did not require accuracy of prediction. It required only a competent level of professional performance, and appropriate responses to positive predictions when they are actually made. The court said:

We recognize the difficulty that a therapist encounters in attempting to forecast whether a patient presents a serious danger of violence. Obviously we do not require that the therapist, in making that determination, render a perfect performance; the therapist need only exercise 'that reasonable degree of skill, knowledge, and care ordinarily possessed and exercised by members of [the psychiatric speciality] under similar circumstances' (9). Within the broad range of reasonable practice and treatment in which professional opinion and judgment may differ, the therapist is free to exercise his or her own best judgment without liability; proof, aided by hindsight, that he or she judged wrongly is insufficient to establish negligence (10).

This: last point bears emphasis, because the Tarasoff case is 'often misunderstood by psychiatrists to require accurate predictions. Literature has increasingly explained that mental health professionals lack the tools to make accurate appraisals of patients' future dangerousness. What the Tarasoff case actually requires is not aocuracy of prediction, however, but exercise of the reasonable proficiency ordinarily expected of mental health professsionals in the circumstances. Mental health professionals can and do make reasonable predictions in their daily practice; what they cannot do is to ensure that their predictions are always right. The law does not require that they be right, nor find them negligent simply because they prove to be wrong. The law expects only that reasonable skill, knowledge and care be brought to bear, in accordance with the standards of the profession established at trial by expert mental health witnesses (11).

In the facts of the Tarasoff case a prediction was made that the patient in fact presented a lethal menace to the specific victim, and, tragically, that prediction was 100 per cent accurate. 
Had a prediction been made that the patient was not dangerous or that the danger was under control, the question would have been whether that prediction was made with the reasonable skill, knowledge and care expected of a professional in the circumstances. If a negative prediction was so made, it would not have been negligent simply because it was wrong. The courts recognize that the burden of exercising clinical judgment is that it may prove to be incorrect, and they will not second-guess the clinician or judge him or her by hindsight.

It was predicted in the Tarasoff case that the patient was dangerous precisely in the way that he proved to be. That raised the question of whether there was an appropriate response to the prediction, and in particular whether any legal duty of care was owed to the specifically predicted victim. The defendants denied that a therapist owes obligations outside the therapist-patient relationship. The court reviewed the background jurisprudence and its evolution, however, and adopted the proposition that:

... there now seems to be sufficient authority to support the conclusion that by entering into a doctor-patient relationship the therapist becomes sufficiently involved to assume some responsibility for the safety, not only of the patient himself, but also of any third person whom the doctor knows to be threatened by the patient (12).

Consistently with this observation, the court fashioned the legal principle that:

... when a therapist determines, or pursuant to the standards of his profession should determine, that his patient presents a serious danger of violence to another, he incurs an obligation to use reasonable care to protect the intended victim against such danger (13).

The Tarasoff case involved a specifically identified victim, but in the Lawson case there were no means to predict that the victim would be Lawson as opposed to any other person to whom the dangerous patient might gain access. The facts of the case concerned a psychiatric patient at the Wellesley Hospital in Toronto. He had been assessed as violent, and was held in secure custody within the hospital. He was allowed to escape, however, and while at large he seriously assaulted Lawson, who was also a patient in the hospital. The victim sued the hospital for its negligence in allowing the escape, and the Supreme Court of Canada upheld the Ontario Court of Appeal's decision that the hospital was legally liable. Hospitals may acknowledge their legal liability to their patients more readily than they recognize liabilities to strangers; the control of spread of infection, for instance, is part not only of health care of patients, but also of legal care. The Supreme Court of Canada expressed its finding of liability more generally, however, and, consistently with the Tarasoff court, found a hospital bound to supervise and to keep under reasonable control patients the hospital knows or ought to know have violent propensities (14).

\section{Liability for Danger}

Both the Tarasoff and the Lawson cases bristle with important implications; many more, indeed, than can be addressed here (15). The Lawson case is in many ways the more significant; it addresses the more general issue of patients who are diagnosed as dangerous, or who, by professional standards of practice, ought to be diagnosed as dangerous, not to any specific individual, but to any one or more of the population at large. The psychiatrist's duty regarding such a patient is to fulfil two functions (below). These are often viewed within the profession as the single function of applying psychiatric care, but the courts have paid regard to the powers psychiatrists (unlike most other physicians) have to compel patients to come under their management who have not volunteered to be detained or treated.

In the Massachusetts judgment now known as Rogers vs. Commissioner of Mental Health (16), it was explained that psychiatrists have two functions. The therapeutic function is secondary among these, although it is the function the profession finds more congenial, authentic and reputable. The primary function is the police function which has to be discharged when persons, who may or may not at the time be patients, are or should be assessed to be dangerous. It is notable that the defendants in the Tarasoff case, who had invoked confidentiality to explain why they did not inform the victim or her family of the danger they predicted, had themselves shared their information with the campus police.

It has been argued that, on the facts of that case, the sole responsibility for the victim's death was that of the police. Dr. Alan Stone, for instance, has claimed that:

$\ldots$ it is the police who are charged with the protection of society and to whom psychotherapists, like other citizens, turn when violence threatens. And it is the police who are trained and armed to protect themselves as well as others from violence. It is the police who can send squad cars to a victim's house to warn him or her (17).

In their 1974 decision (18), the Supreme Court of California held that the police were in fact liable to the victim, but this result was reversed at the 1976 rehearing, on the ground that the police did not have a special relationship with either the student or his victim that was sufficient to give rise to a duty to warn. Both the 1974 and 1976 Tarasoff cases found, however, that the defendant mental health professionals did have such a special relationship, and that their failure properly to discharge the responsibilities of that relationship once they had found a specific danger to the victim, and had learned of police action which failed to remove that danger, rendered them legally liable.

To understand this, some basic distinctions must be drawn. First, if indeed the police do have responsibilities in a given situation it does not follow that others do not. Joint responsibilities can exist such that, if one party fails to act, the other bears the burden of taking appropriate independent action. Thus, even if Dr. Stone is correct in 
alleging police responsibility, it does not follow that the mental health professionals in the Tarasoff case were legally without fault. Second, a distinction exists between being vicariously liable for another's wrong and being directly liable for one's own wrong. Statute almost invariably affords mental health facilities and their employees immunity from liability for wrongs committed by patients. In Ontario, for instance, the Mental Health Act (19) provides in section 63 that:

"No action lies against any psychiatric facility or any officer, employee or servant thereof for a tort of any patient."

This provision reflects the general legal principle that one person is not liable for another's wrong unless a special relationship exists. This principle provides the basis in the 1976 Tarasoff case for holding the police not liable for the student's behaviour. The same provision of the Mental Health Act was also invoked in the Lawson case, and was the basis upon which the Ontario County Court held at trial that the Wellesley Hospital was not liable to Lawson (20).

In the Ontario Court of Appeal, however, it was found that the hospital's liability arose not from the dangerous patient's attack upon the victim, but from the hospital's own negligence in permitting a patient known to be dangerous to escape from secure custody (21). Equally, in Tarasoff, the defendants were held liable not for the student's attack upon the victim, nor for the failure of the police to prevent or restrain the attack, but for their own breach of the duty owed to the victim to respond appropriately when they were aware, according to the assessment they had made in their clinical judgment of the student's propensities, that she remained in danger. Since she was relatively easily identifiable and her family was accessible, discharge of the duty'by notifying her or her family of the perceived danger would not have been especially burdensome.

The fact that psychiatrists' therapeutic functions are distinguishable from their police functions is apparent in the evolution of the criteria for involuntary commitment. Ontario, for instance, reflects an international trend (22), having in 1967 replaced the power involuntarily to commit a person for the purpose of his or her "welfare" with a criterion of "safety." Before 1967, legislation permitted a person's involuntary detention and indefinite confinement if two physicians certified that the person was "mentally ill", meaning "suffering from such a disorder of the mind that he requires care, supervision and control for his own protection or welfare, or for the protection of others (23)." This was changed in 1967 to a "safety" criterion, in legislation restricting a person's involuntary detention to cases in which confinement is "in the interests of his own safety or the safety of others (24)." This criterion was further restricted in 1978 to the present "dangerousness" test of involuntary commitment. Section 14(1)(c) of the Mental Health Act (25) now permits involuntary detention only when a psychiatrist examines a person and: is of the opinion both that the person is suffering from mental disorder of a nature or quality that likely will result in,

(i) serious bodily harm to the person;

(ii) serious bodily harm to another person; or

(iii) imminent and serious physical impairment of the person,

unless the person remains in the custody of a psychiatric facility and that the person is not suitable for admission as an informal patient.

Accordingly, the basis of a person's involuntary commitment is dangerousness rather than treatability, and its primary purpose is to protect the person or a potential victim from the risk of "serious bodily harm." This is a function congruent with that exercised by the police force of a community. Psychiatrists, unlike the police, have no general duty of surveillance of the community, of course, but if in the course of their professional functions psychiatrists assess a person who satisfies this dangerousness criterion under the influence of a mental disorder, psychiatrists have the function, and the legal powers to discharge the function, of a policing nature.

Therapeutic responsibility for a person involuntarily detained under a policing power is a separate matter, since involuntary detention does not necessarily justify involuntary treatment; a person found to be dangerous is not necessarily legally incompetent to grant or to withhold consent to medical care. Persons detained because they have infectious diseases are also dangerous, but they are free to decline treatment and remain in detention. In some jurisdictions of the United States, a legally competent involuntarily detained person can decline therapeutic management with full legal effect (26). In Canada, some forms of therapy may be undertaken on involuntary mental health detainees without their consent and even over their legally competent objections, but the basis of such therapy is not just that they are dangerous, but that they are also amenable to treatment. It has to be seen whether involuntary therapeutic treatment can withstand challenge under the Charter of Rights and Freedoms. Section 7, for instance, protects rights to liberty and security, and the right not to be deprived of them except in accordance with principles of fundamental justice. A court order may be necessary before involuntary therapeutic care can be undertaken.

The only management to which involuntary detainees as such can be subjected on grounds of their dangerousness is by way of restraint. The psychiatric profession, and indeed the wider public, often fails to observe the different functions of policing involuntary detainees and of treating them with a view to assisting them because detainees are usually described, in legislation and popular discussion, as "patients". In fact such detainees in themselves are no more patients of involuntary therapy than are prisoners detained by the correctional service. 
Once danger is predicted, or by professonal standards of competence ought to be predicted, in a person for whom a psychiatrist has a professional responsibility, the duty to take protective action is proportionate to that danger. Danger may come from violence, which may be forestalled invasively by chemical or mechanical restraints or, for instance, by detention in isolation from other people; a suicidal patient will also have to be denied the means of self-injury and be kept under suitable vigilance. The threat patients pose to others or to themselves may not be explicit or externalized, however, but may be implicit. Patients with mental illness may be non-violent and suitable for voluntary treatment as informal patients or out-patients. If they are prone, for instance, to drive recklessly or negligently, however, due to their mental states or due, for instance, to the effects of prescribed medication or of alcohol or illicit drugs they are known to take, it may be considered reasonably foreseeable that they will cause injury. Similar issues arise when a patient may be a source of injury in the workplace, in the home, or elsewhere. A mental health professional responsible for such a patient may be held to be in a special relationship not only to the patient but also to anyone, individually identifiable or not, whom the patient may injure. The Lawson decision widened the net of those to whom a duty of care may be owed, and anticipated the cases in the United States in which the Tarasoff principle has been applied regarding nonidentifiable victims of predictably harmful patients.

In Petersen vs. State (27), for instance, liability was found when a psychotic drug abuser was released from detention although he was known to be likely to drive when he had not taken his prescribed medication. Under the influence of illegal drugs he drove through a red traffic light and collided with the plaintiff's vehicle. It was held that she was owed a duty of care under the Tarasoff principle, even though she was not personally identifiable and warnable before the event. The duty in her case was not to warn her, but to keep in custody a patient who was known, or should have been known in view of his clinical history, to be likely upon release to drive recklessly.

By proposing that a patient who is predicted to be a threat to the safety of others be subjected to reduced confidentiality (when a warning is given to an identifiable prospective victim) or that such a patient be involuntarily detained, the law may seem to act on behalf of prospective victims and against patients. In fact, however, it may be proposed that by urging appropriate action to protect the likely victim, the law is also protecting the patient. Had Miss Tarasoff or her family been duly warned, for instance, not only might she not have been killed, but the student might not have been convicted of murder, and then have been found insane (28).

Nevertheless, where patients are involuntarily detained or kept in detention, mental health professionals may feel that they are reverting to an earlier status of guardians of the mentally disordered who were jailers or warehouse- men. Where the potential victim is unidentified, the burden of detention is imposed upon the known patient when the benefit of protection of another is not so immediate or visible. There may still be a professional judgment to be made on the patient's behalf, however, and that is to commit the patient to psychiatric care rather than to bring in the police; that is, it may be better that psychiatrists exercise their own police powers, in the hope that psychiatric hospitalization may lead to therapy, rather than leave the patient to the uncertain care available through routine police and court services. Dr. Paul Appelbaum has noted "the reluctance of clinicians to see themselves as part of the criminal justice system, 'doing the dirty work' for the police. It is thus much easier and less threatening to the psychiatric selfimage to hospitalize such a patient (29)."

\section{Responses to Predicted Danger}

The psychiatrist's arsenal in the face of a patient's apparent threat to an identified or unidentified victim when the patient is not actually or imminently violent includes all of the voluntary means of care available in the medical management of non-threatening patients. There are circumstances in which anyone could be dangerous. The issue is not so much one of danger but one of risk. Where a patient appears in responsible clinical judgment to be a low risk, for instance while remaining on medication or receiving regular out-patient care, the patient may be managed by less restrictive means. The patient must be kept under close monitoring, of course, and upon a sign of failure to take necessary medication or to attend for out-patient care, or when evidence is found of the patient taking alcohol or illicit drugs, appropriate protective means will have to be taken. As part of informed consent (better called "informed medical decision-making"), the patient should be told of the proposal for monitoring, and of intended professional responses to the patient's departure from the proposed scheme of management. Such responses may be introduced in an agreement or "contract" made with the patient. In an agreement, a patient may accept that, upon his or her commission of a breach of its terms indicating that the patient is in a higher category of risk to do harm than was first diagnosed, an identifiable victim will be informed. This term of an agreement allowing breach of confidentiality may be reinforced by the fact that it conforms to the general law, indicated in the Tarasoff case.

Other responses are more invasive, including involuntary detention for assessment on grounds of acute mental disorder or dangerousness, depending upon the criterion adopted in provincial mental health legislation, and giving information to the police. Particular legislation may also permit or even compel other responses; where child abuse is predicted, for instance, mandatory reports may have to be made by mental health professionals no less than by others to agencies of government or, for instance, to Children's Aid Societies. 
Legally required or legally appropriate responses will be influenced by the person against whom the risk of violence or danger is directed. Certain general categories of prospective victims can be identified, and the special options and conditions relevant to their circumstances can be addressed.

\section{Institutional Professional Staff}

Psychiatrists, psychiatric nurses, psychiatric social workers and comparable professionals know the population with which they deal. They must be afforded reasonable means to be aware of who is assessed to be violent or otherwise dangerous, and be given means of adequate personal protection. Protection may be by imposition of adequate restraints upon the source of danger, through chemical, mechanical or physical means, or by strategies for instance of having two or more staff members involved in any direct dealings with the patient.

Professional' staff are presumed to know the risks of managing a threatening population, however, and are deemed to have agreed with their institutional employers to accept reasonable levels of risk. Their professionalism consists in part in knowing how to predict and forestall danger, and their voluntary decision to practise their profession in the place and manner that they do indicates their willingness to accept its reasonably known risks. If they suffer injury of a nature and origin that they agreed to risk, they are presumed in law to have assumed the responsibility of that risk. They have no legal cause of action against their colleagues, superiors or employing institutions.

This is not to say, however, that professional staff have no remedies against competent but violent or otherwise dangerous patients who injure them. They may sue such patients for compensation, and lay criminal charges leading to punishment and perhaps to orders for payment of compensation. They may alternatively claim payments under provincial criminal injuries compensation schemes, depending upon how the schemes are structured. If professional staff want to ensure their financial security against disability, they may take out private insurance policies, for instance to reinforce their claims to social security benefits or to insurance under any special terms of employment.

The legal proposition in relation to an employer is that a person who volunteers to run a risk has no remedy if the very risk accepted results in injury - this is sometimes called the "assumption of risk" doctrine (30). If the extent of the risk is negligently concealed, however, or if it is negligently increased, for instance when a colleague whom a professional is entitled to rely upon to act competently acts carelessly, a legal claim may succeed against the colleague or the employer for the proportion of a resulting injury attributable to that negligence. If the negligence can be shown to be the sole cause of the injury, compensation may indemnify the victim for the entire loss, but if the negligence simply aggravated a risk the professional had already agreed to run, liability will be apportioned and the victim will recover only for the part of the danger that exceeded the injury the professional consented to risk. This is sometimes referred to as the principle of contributory negligence, or of comparative negligence or fault (31).

\section{Institutional Non-Professional or Service Staff}

Regular non-professional or service staff are entitled to a safe work environment, even if they are employed to care for or to work among dangerous patients. They are not taken to consent to run. special risks, and the power that professional staff have to restrain patients assessed to be dangerous is a duty insofar as an institutional nonprofessional employee is concerned. The Lawson case found liability when a patient was brutally assaulted, but the principle established in the case would have been equally applicable had the victim been a member of the service staff. Unlike professional staff, service staff will not be expected to provide themselves with insurance protection against the risks of their employment. Remedies for injuries caused by a patient negligently allowed to have access to them will in principle lie against their employers, or in some cases against the member of the professional staff who was at fault (see below). It may be, however, that employees' injuries are governed by worker's compensation schemes; if so, they will have no right to sue their employers in the ordinary courts. Patients causing injuries can be sued for their own wrongs, of course, but if evidence indicates that they are not legally competent to answer for their acts, or if they have no financial means to pay compensation, suing them may not provide effective remedies.

\section{Patients}

It is obvious from the Lawson case that patients can succeed in claims against those whose negligence caused them to be injured by other patients who are or should be known to be dangerous. Because informal or voluntary patients are legally entitled to full protection, little is added by pointing out that a more demanding duty may be owed to protect involuntary patients who are not free to leave their place of detention. The same is the case, of course, regarding persons who are involuntarily detained for psychiatric assessment.

It has been seen that even involuntary patients can be legally competent medical decision-makers. As persons who are accountable for their conduct, their provocation of other patients who attack and injure them may reduce or eliminate their claims that their attackers were negligently held in custody. If assaulted patients are not competent and not accountable for the conduct that results in their being injured by way of retaliation or selfdefence, their injuries will raise questions of whether they were adequately protected against their dangerousness to themselves.

\section{Visitors and Strangers}

It follows from what has been discussed above that the same duty of care which is owed to patients in general is 
owed to visitors to institutions guarding or accommodating those who are (or should be) known to be dangerous. Institutions may seek to make it clear to visitors that they enter at their own risk, and that is true in law regarding injuries which no reasonable vigilance could have prevented. Such a warning cannot serve, however, as a shield or licence for negligence. Doctrines of informed consent which transfer the risk of injury to the person who knowingly agrees to run that risk do not protect the party who gives the information from liability for his or her own negligence.

\section{Identifiable Prospective Victims and Family Members}

It is clear from the Tarasoff case that duties of care against dangerous patients are owed to identifiable prospective victims. Many of these are the dangerous patients' family members or others with whom the patients are infatuated or in deep emotional relationships. Those relationships may not, of course, be reciprocated. If identifiable victims are complete strangers (major political leaders, perhaps, or movie stars), the regular duty of protection - to warn the persons concerned, their staffs or the police - will apply.

Where patients and identifiable prospective victims are partners in an emotional relationship, however, it must be asked whether simply warning the victim or the police is an adequate professional response. David Wexler has argued (32) that violence-prone patients who feel hostility toward particular individuals such as spouses or lovers could be more effectively treated not individually but with some form of group therapy, including the presence of the potential victim whose behaviour may trigger the patient's hostility. Wexler has also noted how in domestic violence, until the moment of one partner's striking out, the roles of victim and assailant are often interchangeable (33). This perception may not be applicable in Tarasoff like situations, where the object of a patient's infatuation may regard himself or herself as uninvolved in the patient's life. Even where the potential victim clearly is so involved, he or she cannot, of course, be compelled to participate in group therapy; it may be appropriate, however, for a therapist responsible for the patient to offer the potential victim some appropriate counselling or therapy. It would be over-stating the position, however, to say that a legal duty exists to make such an offer.

\section{Dangerous Patients}

The final category of potential victims to whom legal duties of appropriate management are owed are the dangerous patients themselves. These patients are not just the violent and suicidal ones, but also those who show lack of competence to care for themselves, and may, for instance, suffer malnutrition from an omission to eat, or set fire to their kitchens or bedding. Cases in the United States of psychiatrists and psychiatric facilities being found liable for negligence because, for instance, they permitted patients known to be suicidal to remain unguarded in upper-story rooms with no bars on the windows, are too numerous to mention. The principle of liability applies equally, of course, in Canada, and all such patients may have to be properly detained for purposes of their own safety.

It must be emphasized, however, that a duty of involuntary detention and restraint arises only when the person at risk is found to be suffering from mental disorder. Psychiatrists have responsibilities only for their patients, and only for those of their patients whom they have or should have the professional skill to diagnose as mentally disordered. If a person is found not to be so disordered, but has disclosed an intention, for instance, to rob a bank while armed, the psychiatrist clearly acting in a professional capacity may be held to be in a special relationship to anyone the person may injure, although discharge of the obligations of that relationship may require the psychiatrist only to inform the bank or the police of what is known. It is not obvious, however, that a psychiatrist who encounters such a person is necessarily in a professional relationship. It may be argued, depending on the circumstances, that the relationship is that of ordinary members of society, and that the mental health professional has no more legal responsibility to take protective initiatives than any other citizen. Similarly, when a person who is not mentally disordered determines upon suicide by declining to eat, the British Columbia Court of Appeal has held that there is no legal duty to intervene, even when the person is incarcerated in a penitentiary and power exists to undertake preventive management (34).

\section{Liability of Psychiatric Facilities}

The final issue to be addressed concerns the legal liability of psychiatric facilities, and of general hospitals with psychiatric departments, for negligence committed by their medical staff members, for instance in medical management of violent or threatening patients. The issue was addressed in principle by the Ontario Court of Appeal in the case of Yepremian vs. Scarborough General Hospital (35). This involved a physician who specialized in internal medicine with particular expertise in endocrinology, but the relevant principles in the case are applicable to all medical specialities.

A distinction was recognized in principle between three categories of physicians. The first consists of those who practise in the community, and are not employed by hospitals where they have admitting privileges. Patients retain these physicians by individual choice, and go to the hospitals where by chance the physicians happen to be entitled to admit and perhaps to treat their patients. Hospitals are not responsible to patients for these physicians' neglience, since the critical relationships the patients have are with the physicians and not with the hospitals. The second category is diametrically opposed to the first, and consists of physicians employed and paid salaries by hospitals. The patients they treat have not 
selected them as personal physicians; those patients' critical relationships are with the hospitals, not with individual members of their staffs. Hospitals are legally liable for the negligence of doctors they employ.

The third category raises more difficulty. It consists of physicians who are neither employees of hospitals nor personally retained by patients. They practise only in hospitals, but they bill provincial health insurance plans, and/or the patients themselves, for their services. The trial judge in the Yepremian case found that hospitals are not necessarily just providing these physicians with office and related facilities, in landlord-tenant relationships, but that all of the circumstances must be considered in order to decide whether the hospitals bear non-delegable duties of care to patients which impose liability on the hospitals for the physicians' negligence. He found that, in the circumstances of that case, the hospital was in fact liable. The Court of Appeal reversed that finding by a three-to-two majority, however, and found that the hospital was not liable.

The Supreme Court of Canada granted leave to appeal, but before the appeal was heard the parties reached an out of court structured settlement involving a payment that, depending upon the victim's lifespan, will be from $\$ 1.84$ million to $\$ 2.75$ million (36). The effect of this agreement was to preserve the Ontario Court of Appeal's majority decision. The terms of the settlement offered and to be paid by the successful appellant may suggest, however, a lack of confidence that the Supreme Court of Canada would have favoured the Court of Appeal's decision. The trial judge based his decision on doctrines prevalent in the United States, and the sympathy the Supreme Court of Canada has shown to such doctrines in recent years, particularly in the field of medical law (37), lends support to the view that the trial decision might have prevailed.

In any event, it might be wise policy for psychiatric facilities to act upon the view that they would be held liable for the acts of psychiatrists falling within the third category, whose negligence in medical or other management of violent or threatening patients might result in victims' injuries. The adjustment to this should consist not just in arrangement of insurance protection, but also in ensuring that proper responses will be made to the clinical identification of danger, and in maintaining professional skills at the expected standard of proficiency, as in the case of the second category of physicians employed and salaried by hospitals.

\section{References}

1. (1974), 529 P.2d 553 (Cal.Sup.Ct.) and (1976), 551 P. 2d 334 (Cal.Sup.Ct.). All further references to the Tarasoff case will be to the 1976 judgment of the Supreme Court of California.

2. (1977), 76 D.L.R. (3d) 688.

3. People v. Poddar (1974), 518 P. 2 d 342 (Cal.Sup.Ct.).

4. See Reibl v. Hughes (1980), 114 D.L.R. (3d) 1.

5. Note 1 above, at 346.

6. Ibid. at 347; see also B.M. Dickens, "Legal Protection of
Psychiatric Confidentiality", Int'l J Law and Psychiatry 1978; 1: 255-281.

7. Ibid. at 344 .

8. See for instance C. Webster, B.M.Dickens and S. Addario, Constructing Dangerousness: Scientific, Legal and Policy Implications (1985), Centre of Criminology, University of Toronto; J.W. Hinton, Dangerousness: Problems of Assessment and Prediction (1983); J. Monahan, Predicting Violent Behavior: An Assessment of Clinical Techniques (1981).

9. Citing Bardessono, v. Michels (1970), 478 P. 2d 480 (Cal.Sup.Ct.) at 484.

10. Note 1 above, at 345.

11. See McIntosh vs. Milano (1979), 403 A. 2d 500 (N.J.Super.Ct.) at 511-512.

12. Note 1 above, at 344, citing J.G. Fleming and B. Maximov, "The Patient or his Victim: The Therapists's Dilemma" (1974), 62 California Law Rev. 1025-68, at 1030.

13. Ibid. at 340 .

14. See note 2 above, at 692 .

15. See more generally B.M: Dickens, "Prediction, Professionalism and Public Policy" In: C.D. Webster, M.H. BenAron and S.J. Hucker, Dangerousness: Probability and Prediction, Psychiatry and Public Policy (1985) 177-207.

16. The series of cases changed name as different Commissioners held office; the best known decision in the case is Rogers v. Okin (1979), 478 F. Supp. 1342 (U.S.Dist.Ct., Dist.Mass.).

17. A.A. Stone, Law, Psychiatry, and Morality (1984) at 185186.

18. Note 1 above.

19. R.S.O. 1980 , c. 262.

20. Lawson v. Wellesley Hospital (1974), 44 D.L.R. (3d) 24 (Ont.Co.Ct.). At the time, the present s. 63 was numbered s. 59.

21. Lawson v. Wellesley Hospital (1975), 61 D.L.R. (3d) 445 (Ont. C.A.).

22. See generally W.J. Curran and T.W. Harding, The Law and Mental Health: Harmonizing Objectives (1978).

23. See The Mental Hospitals Act, R.S.O. 1960, c. 236, s. 1(m), and the discussion in B.A. Martin, "Criteria for Civil Commitment: Medicolegal Impasse", in C.D. Webster, M.H. Ben-Aron and S.J. Hucker, note 15 above, at 161-175.

24. The Mental Health Act, 1967, S.O. 1967, c. 185, s.8(l)(a).

25. Note 19 above.

26. See Rogers v. Okin, note 16 above.

27. (1983), 671 P. 2d 230 (Wash.Sup.Ct.).

28. It has been reported that upon release he returned to his native India and is now happily married; see A.A. Stone, note 17 above, at 161 .

29. "Hospitalization of the Dangerous Patient: Legal Pressures and Clinical Responses" (1984), 12 Bulletin Am. Acad. Psychiatry and Law 323-329, at 327.

30. In classical form, it is expressed as volenti non fit injuria.

31. United States' courts are increasingly using the doctrine of contributory negligence in preference to the doctrine of assumption of (the entire) risk; see M.J. Toddy, "Assumption of Risk Merged with Contributory Negligence: Anderson v. Ceddardi" (1984), 45 Ohio State Law J. 1059-1076.

32. D.B. Wexler, Mental Health Law and Major Issues (1981) at 168 .

33. D.B. Wexler, "Patient, Therapists, and Third Parties; The Victimological Virtues of Tarasoff" (1979), 2 Int'l. J. of 
Law and Psychiatry 1-28.

34. $\operatorname{Re}$ Attorney-General of British Columbia and Astaforoff (1983), 6 C.C.C. (3d) 498 (B.C.C.A.).

35. (1980), 110 D.L.R. (3d) 513 (Ont. C.A.).

36. See Yepremian v. Scarborough General Hospital (No. 2) (1981), 120 D.L.R. (3d) 341.

37. See for instance Reibl v. Hughes, note 4 above.

\section{Résumé}

L'auteur examine ici la nature de la responsabilité des professionnels chargés du traitement des patients violents, à la lumière des arrêts Tarasoff (É.-U.) et Lawson (Canada) qui ont marqué la jurisprudence dans ce domaine.

Il devient de plus en plus important de connaître l'interprétation que donnent les tribunaux de la confidentialité, de la dangerosité, de l'obligation de prévenir et de la nature juridique de l'obligation qui existe entre le thérapeute et son patient. L'auteur examine un certain nombre d'autres questions, notamment celle des risques inhérents au traitement des patients qui peuvent se montrer violents après avoir consommé de la drogue. 